Litteratur

1. Andersen EJ. Klimaavtalen bra for folkehelsen. Tidsskr Nor Legeforen 2016 : 136: $280-1$

2. Guhnfeldt C. Da klodens vær ble snudd på hodet. Kronikk i Aftenposten. www.aftenposten.no/meninger/kronikker/Kronikk-Da-klodens-var-ble-snudd pa-hodet--Cato-Guhnfeldt-8362305.html (24.2.2016).

3. Kvam M. Dødelighet og årstid. Norsk helseinformatikk. http://nhi.no/forside/ dodelighet-og-arstid-41662.html (24.2.2016).

\section{Re: Utredning ved mistenkt kronisk utmattelsessyndrom/myalgisk encefalopati}

Hvem skal diagnostisere pasienter med kronisk utmattelse (1)? Helsedirektoratets veileder sier: «Utredningen og diagnostisering av voksne utføres av fastlegen, fortrinnsvis av spesialist $\mathrm{i}$ allmennmedisin. Ved uklare differensialdiagnostiske problemstillinger bør fastlege henvise til relevante spesialister for å komplettere utredningen, men dette er ikke nødvendig for at diagnosen CFS/ME stilles.»

Veilederen sier m.a.o. at det ikke er nødvendig med uttalelse fra psykiater (2).

Artikkelforfatterne fra Nevrologisk og psykosomatisk avdeling ved Haukeland Universitetssykehus ønsker derimot at de henviste pasientene fra allmennlegene skal være psykiatrisk utredet i primærhelsetjenesten før de blir henvist til nevrolog. Pasienten opplever ofte at plagene ikke er psykiske og ønsker derved ikke vurdering av psykiater. Dette innebærer at systemet forventer at allmennlegen selv skal gjøre en psykiatrisk utredning.

Det foregår en rask utvikling mot en integrert forståelse innen medisin, nevrologi, psykologi og psykiatri, om at psyke og soma er i kontinuerlig gjensidig interaksjon knyttet til læringsprosesser. Men det gamle vitenskapelige dikotomi-paradigmet er nedfelt i kulturen som helse- og velferdspolitiske strukturer. I møtet med helsevesenet har derfor allmenheten fortsatt en oppfatning av et nødvendig skille mellom fysiske og psykiske årsaksforklaringer.

Allmennlegen besitter hverken verktøy eller kunnskap gjennom sin utdannelse til å kunne diagnostisere ME-pasientenes symptomtilstand og skille mellom alle differensialdiagnosene (3). Smerteklinikken ved Haukeland Universitetssykehus innkaller rutinemessig fastlegen til tverrfaglig møte angående henviste pasienter med kroniske smertetilstander. Et tverrfaglig tilbud fins ikke for pasienter med kronisk utmattelse. Psykoterapiforskning viser at relasjonen mellom behandler og klient er en viktig faktor for å predikere endring og bedring hos klienten (4). Hvis allmennlegen henviser pasienten til psykiater mot pasientens vilje, vil dette kunne undergrave tilliten i lege-pasient-forholdet, og dermed redusere muligheten for vellykket behandling.

Systemfeilen i utredning av ME-pasientene er dermed omfattende; fra en foreldet institusjonalisert kulturell- og helsepolitisk forståelse av samspillet mellom kropp og sjel, fraværet av tverrfaglig tilnærming, til undergraving av lege-pasient-relasjonen. Dette gjør at en oppdatert utredning og behandling ikke kan finne sted, men stopper i strukturelle problemer utenfor helsevesenets og legepasient-relasjonens kontroll.

Vårt forslag er nå at det offentlige helsevesenet etablerer et utredningsforløp innenfor tverrfaglige samhandlingsteam bestående av spesialister i allmennmedisin (fortrinnsvis fastlegen), nevrologi og psykiatri. Allmennlegens fremste bidrag er kunnskapen om pasientens biografi, mestringsforventninger, og livskonteksten der symptomtilstanden utfolder seg. Livskonteksten reflekterer symptomtilstanden som en uatskillelig psykisk og fysisk enhet $(5,6)$.
Ine Baug Johnsen (f. 1966) er psykolog ved Nevropsykologisk Helsetjeneste Bergen.

Ingen oppgitte interessekonflikter.

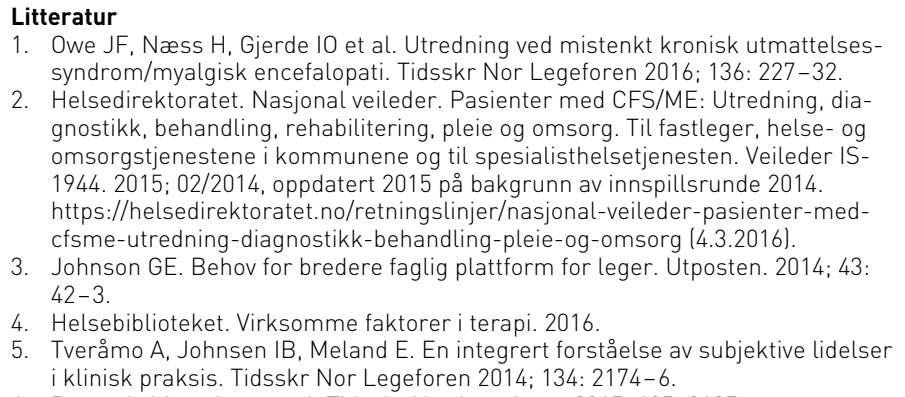

\section{Re: Det syke huset}

Takk for ordene fra redaktøren i Tidsskriftet 3/2016 (1). Legeforeningens medisinske redaktør konstaterer at «Sykehusene lider under systemer som ikke fungerer. Faget skyves til siden, og de ansattes arbeidsglede forsvinner. Det vil kunne gå ut over pasientene».

Sykehuset er blitt Det syke huset. Kan man egentlig undre seg over at sykehusleger vurderer å slutte? Sykehuset er jo blitt omdefinert til en avhippokratisert produksjonsbedrift, om man kan kalle det så. Legene verdsettes som legetekniske medarbeidere hvis viktigste oppgave er å innfri sykehusledelsens produksjonsmål.

I det syke husets styrerom ville man ikke kjenne seg igjen i en slik beskrivelse. Utvikling av helseforetaket er viktigst for styret, med New Public Management (NPM) som overordnet filosofi, og som ledd i et nasjonalt helseforetakssystem. Det er da heller ikke å undres over at det i tillegg til behandlere kreves mange administrative årsverk.

Med manglende kjennskap til praktisk behandling utvikles det teknologiske systemer som ikke er tilpasset sykehusets opprinnelige egenart. For høy beleggsprosent lukker man gjerne øynene for, bare det ikke går ut over produksjonen.

Hvorfor bygger man nye og for små, trange sykehus, mens man samtidig legger ned andre?

Hvorledes skal ansatte og sykehusledelse kunne spille på lag? En ledelse uten etiske forpliktelser vil som premiss for samarbeid forvente lojalitet og samarbeid om foretaksideene og skyve pasientene foran seg. Yrkesetisk forpliktet behandlingspersonell vil måtte henvise til pasientens beste, selv om det skulle stå i motsetning til det ledelsen mener. Mange mener det vil hjelpe at helsevesenet rister av seg NPM og kommer tilbake til forvaltningsmodellen. Det er viktig å «ta faget tilbake». Men uten at man gjeninnfører et Salus aegroti suprema lex (Den sykes vel er den høyeste lov) tror jeg ikke man kommer videre med «høyteknologiske luftslott», for å bruke artikkelens eget uttrykk.

\section{Reidar Schwebs}

schwe1@outlook.com

Reidar Schwebs (f. 1941) er psykiater.

Ingen oppgitte interessekonflikter.

\section{Litteratur}

1. Vangsnes LE. Det syke huset. Tidsskr Nor Legeforen 2016; 136: 203. 